\title{
Blended finance for agriculture: exploring the constraints and possibilities of combining financial instruments for sustainable transitions
}

\author{
Tanja Havemann $^{1}\left[\right.$ C Christine Negra ${ }^{2} \cdot$ Fred Werneck $^{1}$
}

Accepted: 13 July 2020 / Published online: 27 July 2020

(c) Springer Nature B.V. 2020

\begin{abstract}
Transitioning to sustainable agricultural systems is imperative to meet the global Sustainable Development Goals (SDGs). Achieving more sustainable agricultural production systems will require significant additional capital, however this cannot be covered by the current financial market setup, which dissociates public and private funders. Blended finance, where concessionary development-oriented funding is used to mobilize additional private capital, is essential. To ensure that the limited pool of concessionary funding is used efficiently and effectively, a shared understanding of the roles and limitations of public and private funders is necessary. In this paper, we describe the high-level funding gap for sustainable agriculture, the general landscape of agricultural finance, and the concept and potential roles of blended finance in this context. This paper introduces the conditions under which different financing mechanisms can contribute to addressing barriers related to sustainable agriculture investments. It highlights that multiple funding modalities must be utilized in order to achieve agricultural investment at a meaningful level and encourages greater exploration of the range of blended financing structures to increase SDG-related agriculture investments.
\end{abstract}

Keywords Blended finance $\cdot$ Investment $\cdot$ Finance $\cdot$ Agriculture $\cdot$ Agribusiness $\cdot$ Impact investment $\cdot$ SDGs $\cdot$ Sustainable agriculture $\cdot$ Climate smart agriculture

\section{Background}

The agricultural sector is central to achieving many of the United Nations 17 Sustainable Development Goals (SDGs). According to the United Nations Food and Agriculture Organization (FAO), for example, nearly 821 million people faced chronic food deprivation in 2017 (FAO et al. 2018). The number of extreme climate-related disasters has also doubled since the early 1990s, negatively affecting agricultural production and food availability. The environmental footprint of human population growth and dietary shifts has contributed to an over-exploitation of resources by the agricultural sector. For example, agriculture accounts for over

Tanja Havemann

th@clarmondial.com

$\triangle$ Christine Negra

christine@versantvision.com

Clarmondial AG, Zürich, Switzerland

2 Versant Vision LLC, New York, USA
$70 \%$ of global freshwater use, $23 \%$ of total anthropogenic greenhouse gas (GHG) emissions, and to rapidly declining biodiversity (IPCC 2019). Agriculture-induced environmental changes undermine agricultural productivity itself triggering profound socio-economic and political repercussions.

As an engine of socio-economic growth in emerging and developing economies, the agriculture sector is central to development. According to the FAO, while agriculture currently contributes circa 3\% to global Gross Domestic Product (GDP), in Least Developed Countries (LDCs) the agricultural sector can account for as much as $60 \%$ of national GDP (FAO, World Bank Data). In countries with large rural populations, agriculture is critical for domestic food and income security.

To increase sustainability, a wide range of investments is necessary across the diverse set of agricultural systems and stakeholders, addressing a variety of socio-economic and environmental challenges. Across the world, challenges range from poverty inequality, rural depopulation (ESPON 2017), ageing, and obesity to soil degradation and inadequate access to inputs, technology, and infrastructure. 
Expected to be home to 9 out of a projected 11 billion people in 2100, South Asia and Sub-Saharan Africa will demand particular support for sustainable rural economic development (FAO 2017). For example, as highlighted by a recent report by the International Fund for Agricultural Development (IFAD 2019), the majority (65\%) of the world's rural youth (those aged 15-24) live in Asia and the Pacific region, but the number of rural youths in Africa is expected to rise by almost $20 \%$ in the next 3 decades-these youths are approximately three times more likely than adults to be unemployed. Significant additional investment is required to ensure that these individuals are given meaningful socioeconomic opportunities, to ensure that their local societies meet basic livelihood needs, their nations prosper and that they contribute to the sustainable management of the world's natural resources.

While significant geographical differences exist, human diets have become more similar across the world by an average of 36\% over the last 5 decades (CGIAR 2014). Global production is now centered on a genetically homogenous set of crops: wheat, rice, maize, potato, soybean, sunflower oil, and palm oil (CGIAR 2014). Efforts to reduce yield gaps could go some way to addressing increased demand for these products (FAO and DWFI 2015), however such efforts may become increasingly strained due to climate change (Zhao et al. 2017) and low resilience associated with poor agricultural biodiversity (Bioversity International et al. 2017).

Climate Smart Agriculture (CSA), "an approach to developing the technical, policy, and investment conditions to achieve sustainable agricultural development for food security under climate change" (FAO 2013) should be center stage when considering which investments to prioritize for investment, noting that suitability of a specific technology or practice will be site-specific. According to the FAO (2013), CSA "aims to enhance the capacity of the agricultural systems to support food security, incorporating the need for adaptation and the potential for mitigation into sustainable agriculture development strategies". It is composed of three pillars: (1) sustainably increasing agricultural productivity and incomes; (2) adapting and building resilience to climate change; and (3) reducing and/or removing greenhouse gases emissions, where possible. The pathways to achieving sustainable land use (and agricultural) systems are increasingly known i.e. as recently described in the Report of the FABLE Consortium (2019), but pursuing these pathways requires significant additional investment. The FABLE 2019 Report summarizes ten global targets across seven intervention areas, each of these global targets will require changes to three fundamental pillars; (1) Efficient and resilient agriculture systems, (2) Conservation and restoration of biodiversity, and (3) Food security and healthy diets. In order for this to happen, it must be accompanied by changes to policy and regulations as well as significant additional capital (investment) from both public and private sectors, including in research and development, infrastructure, capacity building and accompanying credit.

Although agriculture investment has been rising in high, middle, and low income countries since the 1990s, it has been growing at different rates and capital intensities (FAO 2017). For example, in the People's Republic of China, agricultural growth increased by $9 \%$ annually between 1991 and 2014 , compared to $2 \%$ in high income countries and around $4 \%$ for other low and middle income countries (FAO 2017). The capital intensity of agricultural production diverges across high, medium and low income countries, with generally more capital intensive agriculture in high income countries. This trend is being followed by certain emerging markets, including China (FAO 2017). The FAO, the International Fund for Agricultural Development (IFAD), and the World Food Programme (WFP) estimate that USD 265 billion per year of additional investments are required to end hunger by 2030 . However, these agencies acknowledge that the types of investments vary greatly-from basic infrastructure investments in LDCs to development and distribution of more resilient crop varieties (FAO 2017). Thus, prioritizing agricultural investment needs should be done on a contextspecific basis.

While there is broad agreement that agriculture should be 'more sustainable,' as noted in the Brundtland Report, it should be done in a manner that meets the needs of the present without compromising the ability of future generations to meet their own needs (United Nations 1987). The seminal Brundtland Report, also known as Our Common Future, was published by a high-profile international group and was critical in proposing the concept of sustainable development that is still in use today, namely that such development requires a balance between the environment, social equity and economic growth (United Nations 1987). The Brundtland Report, and the global development community thus recognizes the need for balancing inter alia agricultural productivity (for food, fuel, fiber, and feed), health and nutrition, employment opportunities, equality, human rights, environmental goods and services, and economic wealth. In many cases, the information and information systems required to properly assess and calibrate potential trade-offs among these diverse needs is generally lacking (Clarmondial et al. 2019). This paper does not seek to define sustainable agriculture, as many other authors tackle this topic (Velten et al. 2015). Rather, it focuses on how blended finance approaches could be applied to support the development of a sustainable agricultural sector.

Despite ongoing definitional challenges, it is clear that sustainable agriculture will remain a critical area for international cooperation in order to meet globally agreed objectives such as the SDGs. In addition to an improved understanding of the agricultural sector, it will be necessary to 
mobilize additional funding to implement relevant investment strategies (Global Center on Adaptation and World Resources Institute 2019). Yet, public resources are insufficient: the funding gap to achieve the SDGs is estimated at nearly USD 4 trillion annually, with at least USD 300 billion required to meet the SDGs related to food security (UNCTAD and Convergence). The SDGs will not be reached without significant additional investments by the private sector, including private funders. Small and Medium sized Enterprises (SMEs) in particular are expected to play a critical role in supporting the transition to sustainable agriculture, but face challenges in accessing appropriate financial services (AGRA 2019). Mobilizing additional finance from the private sector-in particular towards relevant agricultural SMEs-will be critical to address the agriculture sector challenges. Blended finance encompasses potentially useful approaches to fill this funding gap.

\section{Agricultural finance: investment approaches and institutions}

As with other sectors, a wide variety of financial instruments is potentially available to finance agricultural projects. The type of financial instrument used should be appropriate for inter alia the development stage, amount required, cash flow profile, risk-return estimates, regulatory landscape, profile of potential funders, owners, and beneficiaries. Private sector actors, both agri-businesses (including cooperatives) and funders, expect that an investment provides an adequate level of return for the risk taken. Key considerations include the potential liquidity, structure, size, and other values that the proposed investment may contribute to an investment portfolio (e.g. correlation with existing assets).

Agricultural investments may span a wide range of opportunities, including early stage technology investments. Some common investments include agricultural technology ('agtech') venture capital, participation in established companies (i.e. private equity), shares of large publicly traded companies (i.e. listed equities), and publicly and privately issued debt (e.g. bonds, notes). Alternative strategies include financial derivatives ${ }^{1}$ and CAT bonds ${ }^{2}$ as well as new forms

\footnotetext{
1 According to Investopedia, "A financial derivative refers to a contract between two or more parties whose value is based on agreedupon underlying financial asset or set of assets. Common underlying instruments include bonds, commodities, currencies, interest rates, market indexes, and stocks... [the] value is derived on the value of the primary security that they are linked to...futures contracts, options, swaps and warrants are commonly used derivatives.".

2 According to Investopedia, CAT bonds (catastrophe bonds) are a "high-yield debt instrument designed to raise money for companies in the insurance industry in the event of a devastating natural disaster. A CAT bond allows the issuer to receive funding from the bond only if specific conditions occur such as an earthquake or tornado. However,
}

of more decentralized finance such as security token offerings (STOs) ${ }^{3}$ and crowdfunding. ${ }^{4}$ These different types of investment modalities suit different types of financing needs.

Investments, or funding more generally, may originate from a range of sources that weigh non-financial (i.e. environmental or social impact) and financial outcomes, and derive from public or private sources. Private sector ('commercial') investors will typically seek risk-adjusted financial returns in line with comparable investments, based on fiduciary responsibility to their beneficiaries (e.g. customers, pensioners, shareholders) to pursue a set of investment strategies and targets. While some initiatives seek to broaden the scope of fiduciary responsibility and better consider environmental, social, and governance (ESG) issues in decision making, these can still be considered nascent. The public sector may provide funding in the form of concessionary and, or commercial capital.

A range of funders sit 'in-between', balancing their expectation of financial return with the intent to achieve measurable positive developmental impacts (i.e. non-financial returns). Thus, 'development finance' is a broader term encompassing Overseas Development Assistance (ODA) and non-concessionary funding by Development Finance Institutions (DFIs), which primarily provide finance for investments that promote development objectives (Swiss Sustainable Finance Glossary). The term 'impact investment' is used in a similar context, referring to "investments made with the intention to generate positive, measurable social and environmental impact alongside a financial return" (GIIN). As a result, the expected financial return may be reduced or the risk appetite increased.

\section{Blended finance}

The OECD refers to blended finance as the "strategic use of development finance for the mobilization of additional finance towards sustainable development in developing countries" (OECD 2018a, b) to address the SDG funding

\section{Footnote 2 (continued)}

if the special event protected by the bond triggers the payout to the insurance company, the obligation to pay interest and repay the principal is either deferred or completely forgiven.".

3 These are financial securities that have a digital wrapper. They include standard underlying investments (e.g. stocks, bonds, real estate) but represented by a token which investors can buy. These are actual assets, linked to the standard regulatory and compliance architecture, though they are banned in some countries (notably China and South Korea)

${ }^{4}$ According to Investopedia, this refers to the application of small amounts of capital from a large number of individuals to finance a new business venture, typically through using social media platforms. 
gap. ODA providers and DFIs are increasingly considering the role of blended finance in their mandates.

There are important nuances within and between the aforementioned definition and other definitions that can make the term 'blended finance' deceptively complex. For example, there is disagreement if philanthropic capital, e.g. grants from foundations can be classified as 'blended finance'. For a discussion of the definitional aspects, refer to ODI (2019).

Two central themes in blended finance concern determining and monitoring additionality and ensuring data comparability (ODI 2019). According to the Business Dictionary, the term "additionality" refers to the "extent to which a new input (action or item) adds to the existing inputs (instead of replacing any of them) and results in a greater aggregate." In the context of blended finance, additionality is sought both in the form of new funding mobilized and development outcomes. According to the OECD Glossary of Statistical Terms, comparability is "the extent to which differences between statistics from different geographical areas, non-geographical domains, or over time, can be attributed to differences between true values of the statistics. Different stakeholder groups have been collecting and disclosing varying information on development finance, and this can make it difficult to form an accurate picture of trends and thus to define priorities and recommend actions. Practically, blended finance refers to the combination of capital that has commercial risk-return expectations with funding that is concessionary in some form (typically from a public funder), in order to generate additional measurable developmental impact (ODI 2019). Financial and developmental additionality is critical (i.e. more capital flows to development strategies than otherwise would), but often challenging to determine due inter alia to a lack of comprehensive data sets and sectoral complexity (Pereira 2015; Carter et al. 2018).

According to ODI (2019) the three key pillars of blended finance are (1) The use of concessionary capital. This form of "below market" capital typically comes from the public sector; (2) That such concessionary capital should mobilize additional finance with non-concessionary objectives, i.e. from the private sector; and, (3) That additional, measurable, development impact is generated as a result. For example, a development agency that provides a partial guarantee to an investment fund that lends to selected agricultural businesses in emerging markets that manage for additional social and environmental impact as well as financial performance, in order to reduce the perceived risk and attract private investment in such a fund.

For the purpose of this paper, we propose the following definition: "the strategic use of concessionary funding mechanisms in order to mobilize additional private finance to achieve additional, measurable, non-financial development (impact) outcomes". This has three aspects that are important to highlight: First, it is inclusive as to the source of concessionary funding, recognizing that such funding can be broader than traditional development funders and instruments. For example, concessionary funding could also come from a private foundation. Second, it clarifies that the purpose is to mobilize additional finance (capital), rather than other goods and/or services. And, third, it highlights that the intent is to have measurable additionality of non-financial (social, environmental) impacts-typically related to achieving the Sustainable Development Goals (SDGs).

The concept of 'blending' is not new. For example, the first government-supported export credit insurance agency in the UK was established in 1919 to support the private sector to undertake more international business (UK National Archives). The term 'blended finance', however, was first adopted by the United Nations in 2015 at the Addis Ababa Action Agenda (AAAA) of the Third International Conference on Financing for Development (IDFC 2019). In 2016, the High Level Meeting of the OECD Development Assistance Committee (DAC) secured commitments by national governments to explore the role of blended finance in delivering the SDGs, notably focusing on the evidence base, best practices, and policy guidance (OECD).

Many historical transactions using a blended finance approach may not have been classified as such. Currently, approximately USD 140 billion worth of transactions have been identified and these types of structures have grown steadily over the past few years (while remaining a small fraction of overall development assistance) (Convergence 2019). Convergence, a global network focused on blended finance, notes that the median transaction size is USD 64 million, and that funds or collective investment vehicles (CIVs) are the most common transaction type. Transactions have mostly focused on Sub-Saharan Africa and have had relatively small deal sizes (ca. USD 55 million), however Asia has demonstrated greater growth. Agriculture has commanded on average $15-21 \%$ of blended finance resources. To date, most blended finance transactions have utilized concessional debt or equity, followed by technical assistance funds, then guarantee/risk insurance, and lastly grants.

While evidence is still emerging, early observations from OECD (2018a, b) and others indicates that the blending of commercial and concessionary capital does not always lead to superior development results. Development finance experts and practitioners also emphasize the need to adapt the financial structure to the development intervention rather than choosing a particular financial structure because it is en vogue. This also requires that the motivations and thus incentives of different stakeholders need to be understood from the start. Where the appropriate financial structure is employed, positive effects on development have been observed. The amount of concessionary capital (subsidy) required to entice private investors has also been observed 
to be linked to the level of perceived investment risk-and thus the potential for each public sector dollar to result in additional private capital. However, calibrating additionality, and thus the value of pursuing a blended finance approach, is challenging as data are insufficient for evaluating and building the necessary evidence base. More effort is required to strengthen accountability, both on financial and non-financial i.e. development performance (OECD 2018a, b).

Important analytic work on blended finance in the agriculture sector is being done, notably by the Council on Smallholder Agricultural Finance (CSAF), "an alliance of financial institutions serving small- and medium-sized agricultural enterprises (SMEs) in Africa, Asia and Latin America... to share learning and develop industry standards and best practices for agricultural SME finance" (CSAF 2019). In 2019, CSAF facilitated an analysis of 4000 agricultural SME loans totaling USD 2.7 billion made by 20 financial institutions to determine loan-level profitability. As a result, it was possible to identify areas where subsidies may be justified: to support smaller loans, loans to African businesses, informal value chains, loans to new borrowers, and long-term (more than 12 month) loans. This research, and the collaborative loan monitoring and information sharing enabled by CSAF, may create an opportunity for determining additionality and thus contribute to developing and refining blended finance structures.

Blended finance can improve the risk-return characteristics of an investment by mixing capital flows with different financial and non-financial return expectations within an investment structure. Where public budgets are limited, such investment structures may help mobilize more funding from the private sector in support of the SDGs. In the context of agriculture, this may mean using public funding to enable private investors to make investments they may otherwise perceive as too risky, for example with new investment counterparts or in new funding structures. In particular, much attention given to increasing the participation of private sector investors - and in particular 'mainstream' institutional investors such as pension funds in such blended finance structures, yet this appears to be relatively nascent to date. According to the Global Impact Investing Network (GIIN) 2019 annual report, pension funds, insurance companies, and diversified financial institutions only represent $18 \%$ of all impact investments. Agriculture represented $10 \%$ of invested capital with energy, microfinance, and financial services in the lead. Tepid engagement by more 'mainstream' investors and relatively low private capital flows into sustainable agriculture is largely due to the lack of government support, suitable exit options, appropriate capital across the risk/return spectrum, and deal structures that can accommodate investors' or investees' needs. While the growth of the impact investing market is very encouraging, it remains small in the context of global financial markets, or indeed when compared to more passive' strategies such as negative screening. Despite the relatively small current market size, many stakeholders are excited about the potential role of blended finance in mobilizing more investment in support of the SDGs, including for sustainable agriculture.

There are a variety of reasons for taking a blended finance approach. These reasons do not only include public sector budget constraints, but also other motivations such as building investor confidence in new investment counterparts and approaches. For example, including a risk-absorbing tranche in an investment fund may give commercial investors the confidence to invest larger amounts in a strategy than they may otherwise have done, thus increasing the budget for pro-development outcomes associated with such investment. In the case of a new investment fund manager or financing approach, a partial guarantee supported by the public sector may help mitigate presumed investor risk in the initial deployment phase. Blended finance may also be to reward additional development results achieved, i.e. in the case of Results Based Financing, which can be defined as "any program where the principal sets financial or other incentives for an agent to deliver predefined outputs or outcomes and rewards the achievement of these results upon verification" (Musgrove 2011). This may result in the provision of additional resources alongside a commercial financing structure to help increase or ensure development outcomes, e.g. by adding a technical assistance or monitoring and evaluation component or facility to an investment fund focused on small and medium-sized enterprises.

There are many financial instruments, and combinations of financial instruments, that can be used to 'blend'. These include grant funding (e.g. for technical assistance) as well as concessionary versions of existing financial instruments including concessionary debt (i.e. debt provided at softer terms such as longer grace periods and lower interest rates), risk absorbing equity, and subsidized guarantees and insurance mechanisms. The potential roles and financial instruments are described in Table 1.

However, there are limitations of using blended finance. It is important to note that agreement on the boundaries of blended finance remains elusive. This is a challenge for the agriculture sector given its links to the 'real economy', which is defined by the Cambridge Dictionary as "the part of a country's economy that produces goods and services, rather than the part that consists of financial services such as banks, stock markets, etc." The agricultural sector is heavily influenced by government policies in most countries. Policy approaches to expand agricultural finance include national guarantee funds, subsidized lending, forced lending, and interest rate caps. Government interventions that support additional agricultural investment are at the boundary of what might be considered blending. For example, governments can support local subsidized lending programs to 
Table 1 Potential roles of concessionary capital in financial instruments

\begin{tabular}{|c|c|c|}
\hline Role of development finance & Sample instruments & Additionality aspects \\
\hline Identify and enable new financing structures & Grants, concessional loans & $\begin{array}{l}\text { Research to identify opportunities } \\
\text { Facilitate the design of new investment structures }\end{array}$ \\
\hline Seed new structures-first (anchor) capital & Equity, debt & $\begin{array}{l}\text { Test new types of intermediation structures (i.e. proof of } \\
\text { concept funding) and help to bring a financial instrument } \\
\text { to scale, so additional private capital can engage (Milken } \\
\text { Institute and OECD 2018) } \\
\text { Conduct professional due diligence that can be shared with } \\
\text { potential investors } \\
\text { Act as a transaction lead and reference source to other } \\
\text { investors }\end{array}$ \\
\hline Risk mitigation & $\begin{array}{l}\text { Guarantees, first loss tranches, } \\
\text { subordinated loans, risk absorbing } \\
\text { equity }\end{array}$ & Change the risk-return perception for private investors \\
\hline Technical support & Grants & $\begin{array}{l}\text { Provide grant funding alongside an investment to help } \\
\text { increase chances of success (e.g. technical assistance) }\end{array}$ \\
\hline Reward additional development impacts & Grants & $\begin{array}{l}\text { Assigns a financial value to an additional non-financial } \\
\text { outcome }\end{array}$ \\
\hline Market development & Grants & $\begin{array}{l}\text { Research and publish reports on the success of different } \\
\text { interventions } \\
\text { Support the development of investor incentives (e.g. policy } \\
\text { changes) } \\
\text { Support the development of consistent ways to monitor } \\
\text { financial and developmental impact, to appropriately } \\
\text { subsidize additional support, and regional approaches to } \\
\text { harmonize relevant data }\end{array}$ \\
\hline
\end{tabular}

specific sectors or activities by issuing government bonds that attract private capital. Additional private capital may thus be mobilized and may generate additional development benefits (in particular where the use of proceeds of such a government debt issuance are clearly defined and monitored). Local governments may also implement fiscal incentives such as tax holidays and tax rebates to spur private investment in sustainable agriculture interventions. In this case, there may be foregone income to the public purse or public funding may reward certain private investors operating in the agricultural sector after they have done a specific activity that generates a development impact.

\section{Challenges and opportunities for using blended finance for sustainable agriculture}

The wide range of financing needs for sustainable agriculture includes early stage technology investments (i.e. venture capital), long term investments in greenfield production, new infrastructure and processing equipment, investments in transport and utilities, working capital, and trade finance. Such funding mechanisms can be designed to better address sustainability concerns, although doing so may incur additional costs (e.g. for impact monitoring) without direct financial returns.
Some of the challenges that investors face in making investments in emerging and developing markets, including in the agricultural sector, are summarized in Table 2. These are based on the practical experience of the authors, and some of these challenges pertain to investments in emerging markets more generally e.g. as described in GIIN (2019). Some of these challenges are heightened in particular types of agricultural investments. For example, greenfield agriculture investments in emerging markets often carry higher risk and are more challenging to finance given long investment terms and thus higher exposure to political, market and weather risks. While the challenges listed in Table 2 below are not necessarily unique to agriculture, many of these challenges are inter-related and also are exacerbated in developing and emerging markets, in the absence of a supportive policy environment, and where customers and shareholders are price sensitive.

Development Finance Institutions (DFIs) in OECD countries maintain an extensive overview of direct private finance mobilization rates. According to their most recent data assessments, mobilization rates in agriculture are highest when using guarantees, syndicated loans, and credit lines respectively (OECD 2019). In terms of banking and financial services, mobilization rates tend to be highest for guarantees and credit lines-however, it is unclear how much of this segment also tackles agriculture. Data are unavailable for 
Table 2 Selected challenges related to sustainable investments in emerging and developing markets

\begin{tabular}{|c|c|c|}
\hline Challenge & Description & Implications \\
\hline Quality of data for decision making & $\begin{array}{l}\text { There is a lack of up-to-date, dynamic data in } \\
\text { many contexts }\end{array}$ & $\begin{array}{l}\text { Investors and investees may not be able to cred- } \\
\text { ibly measure and demonstrate impact }\end{array}$ \\
\hline Lack of precedents or comparable investments & $\begin{array}{l}\text { There are few example transactions that inves- } \\
\text { tors can use to benchmark an opportunity }\end{array}$ & $\begin{array}{l}\text { Novelty and uncertainty make it difficult to } \\
\text { assess the proposed transaction }\end{array}$ \\
\hline $\begin{array}{l}\text { Unsupportive or unpredictable policy environ- } \\
\text { ment }\end{array}$ & $\begin{array}{l}\text { International or domestic policies that can } \\
\text { significantly change the economics of an } \\
\text { investment }\end{array}$ & $\begin{array}{l}\text { Investors attribute additional risk to an invest- } \\
\text { ment }\end{array}$ \\
\hline $\begin{array}{l}\text { Creditworthiness of potential investment coun- } \\
\text { terparties }\end{array}$ & $\begin{array}{l}\text { Potential investees have unknown or poor } \\
\text { creditworthiness }\end{array}$ & $\begin{array}{l}\text { Risk might be too large for most investors, or } \\
\text { terms unattractive for such counterparties }\end{array}$ \\
\hline $\begin{array}{l}\text { Inefficient transactions size and high interme- } \\
\text { diation cost }\end{array}$ & $\begin{array}{l}\text { Relatively small transactions that are resource- } \\
\text { intensive for investors to properly assess }\end{array}$ & $\begin{array}{l}\text { Transaction cost makes the proposed return } \\
\text { unattractive }\end{array}$ \\
\hline Investment term, expected time to profitability & $\begin{array}{l}\text { Long time required for repayment, in particu- } \\
\text { lar for greenfield or infrastructure invest- } \\
\text { ments }\end{array}$ & $\begin{array}{l}\text { Long term commitment results in higher return } \\
\text { requirement }\end{array}$ \\
\hline Investment liquidity & $\begin{array}{l}\text { The difficulty (or inability) of selling or exit- } \\
\text { ing an investment, e.g. transferring a loan }\end{array}$ & $\begin{array}{l}\text { Investors attribute higher risk to more illiquid } \\
\text { investments }\end{array}$ \\
\hline International currency movements & $\begin{array}{l}\text { Investments in a different (local) currency } \\
\text { results in additional risks to the (foreign) } \\
\text { investor }\end{array}$ & $\begin{array}{l}\text { Investors may avoid certain currencies due to } \\
\text { associated exchange risk }\end{array}$ \\
\hline
\end{tabular}

mobilization rates in structures that are not clearly labeled as 'blended finance' or where OECD DFIs do not participate.

\section{Opportunities for using blended finance for sustainable agriculture}

\section{Equity investments}

Ownership of shares in agriculture-related companies can either occur through the public markets ('listed equities') or through private dealings ('private equity'). A company's business model may relate to the ownership and operation of land, technology, or provision of goods and services. Equity investments may be minority or majority (controlling) positions and may have different levels of business-related risk. Investors usually realize financial returns through dividend payments by the company or by exiting the investment (i.e. sale of shares). Shares can be valued in many forms (e.g. according to the price paid by a third-party in a later transaction). An introduction to public versus private equity investments can be found at Investopedia. An overview of equity based blended finance instruments for agriculture can be found in SAFIN (2019).

Most development-oriented equity investments have been in the form of mezzanine/quasi-equity (preferred shares, subordinated debt) (GIIN 2018; ADB et al. 2017; Blue Orchard 2018). Equity in agricultural investments are generally expected to generate higher returns, due to higher risk and lower liquidity. Illiquidity is considered to be a particular challenge to mobilizing more equity investment. While it would, in theory, be possible to structure various forms of liquidity facilities and equity derivatives (e.g. options, futures) to help attract private capital, this area has not been widely addressed. While some governments have created incentives that encourage public listing of smaller companies, including agricultural companies, barriers such as illiquidity and relatively high costs persists in many emerging and developing markets, hindering capital flows between investors and companies (e.g. Oliver Wyman and World Federation of Exchanges, African Capital Markets News).

\section{Debt investments}

Various forms of debt (i.e. credit) may be provided directly to users (e.g. agricultural companies) or through third-party institutions (e.g. banks or non-bank financial institutionsNBFIs). Debt can be relatively short-term credit (e.g. working capital, trade finance, supply chain finance) as well as longer-term finance for greenfield and capital investments. Investors are repaid according to a pre-agreed timeframe and interest rate. In the agricultural sector, it can be difficult to properly assess and administer loans as borrowers may be geographically remote or informally structured, as well as highly variable in their business models. In addition to relatively common financial products (e.g. direct loans and credit lines through local financial institutions), more concessionary types of financial instruments are possible such as soft loans (e.g. interest-free advances), impact bonds, and subordinated loans. An overview of debt based blended finance instruments for agriculture can be found in SAFIN 
(2019). Table 3 below provides an overview of debt-based blended finance instruments for agriculture.

Note that other tools exist that sit between debt and equity e.g. quasi-equity structures (EIB 2017) and the 'demand dividend' (Santa Clara University 2013) structures (debt vehicles where payments are tied to cash flows, including a grace period, fixed payoff amount, and term sheet covenants and business plan focused on cash to align incentives).

\section{Guarantees and insurance}

Various commercial and concessionary guarantee and insurance products are available. These include instruments that cover political risk, production-related events (including weather), price fluctuation, and performance risk (see Table 4). Different risk mitigation products for agriculture are explored in Dalberg Global Development Advisers (2018) and World Bank Group (2014).

\section{Grants}

Grant funding can be used to support product development costs, to deliver technical assistance (TA), and to reward performance. In some cases, this takes the form of challenges or prizes. An overview of grant based blended finance instruments for agriculture can be found in SAFIN (2019), and is summarised in Table 5.

Table 3 Overview of debt-based blended finance instruments for agriculture

\begin{tabular}{ll}
\hline $\begin{array}{l}\text { Approach } \\
\begin{array}{l}\text { Bonds, notes and other direct loan, } \\
\text { including credit lines e.g. for trade, } \\
\text { export, }\end{array}\end{array}$ & $\begin{array}{c}\text { Role of development funder } \\
\text { of a dedicated agriculture credit line through an existing financial institution }\end{array}$ \\
$\begin{array}{l}\text { Soft loan (interest free advances) } \\
\text { Provide a direct loan that bears no interest. A development funder may advance payment for a good or } \\
\text { service, ahead of that good or service being delivered, effectively providing credit at no cost }\end{array}$ \\
$\begin{array}{l}\text { Provide upfront investment, or act as the outcome funder to subsidize private investment into an instru- } \\
\text { ment }\end{array}$ \\
$\begin{array}{c}\text { Provide funding in a more junior position in the capital stack compared to other private funders, thus } \\
\text { accepting lower returns or higher risk, or both }\end{array}$ \\
\hline
\end{tabular}

Table 4 Overview of guarantees and insurance blended instruments for agriculture

\begin{tabular}{lc}
\hline Approach & Role of development funder \\
\hline Credit guarantee & $\begin{array}{l}\text { Cover certain potential losses incurred by agricultural lenders } \\
\text { Production insurance }\end{array}$ \\
$\begin{array}{l}\text { Cover certain potential production-related losses, e.g. due to weather, climate, pests or disease. This may } \\
\text { be done directly (i.e. via insurance policy), or through financial instruments }\end{array}$ \\
$\begin{array}{l}\text { Cover certain potential market-related losses, including on volumes, price fluctuation and currency. This } \\
\text { mayment, performance, surety bonds done directly (i.e. via insurance policy), or through financial instruments }\end{array}$ \\
$\begin{array}{c}\text { Commonly used in real estate and trade finance, these bonds de-risk a transaction between providers and } \\
\text { buyers of goods/services. Development funders may subsidize these directly or through a third party } \\
\text { (e.g. insurance company) and may participate directly (e.g. provide letters of credit (LCs) and reserve } \\
\text { accounts as a form of guarantee) }\end{array}$
\end{tabular}

Table 5 Overview of grant based blended finance instruments for agriculture

\begin{tabular}{ll}
\hline Approach & Role of development funder \\
\hline Technical Assistance (TA) & $\begin{array}{r}\text { Pay for TA to farmers, local companies, or intermediaries (e.g. for agronomic or business management expertise) } \\
\text { in order to reduce credit risk }\end{array}$ \\
$\begin{array}{l}\text { Performance-based grants } \\
\text { Pand Results Based }\end{array}$ & $\begin{array}{l}\text { impact) outcomes, typically once these have been verified by an independent third party. This could increase, } \\
\text { firectly or indirectly, the return of other funders }\end{array}$ \\
$\begin{array}{l}\text { Design funding } \\
\text { Provide grants to entities that develop and implement new business models or financial instruments to mobilize } \\
\text { additional capital to sustainable agriculture }\end{array}$ \\
$\begin{array}{l}\text { Provide a sum of money to an entity that has won a competition to achieve a specific pre-defined result. This differs } \\
\text { from performance-based grants in that it is competitive, and that performance-based grants do not necessarily } \\
\text { require third-party verification }\end{array}$
\end{tabular}




\section{Discussion}

While private capital providers increasingly seek sustainability impact alongside financial returns, the challenges they face in deploying more funding to sustainable agriculture need to be considered. There are technical challenges (e.g. information ecosystem gaps for evaluating tradeoffs) as well as operational challenges on how to mobilize appropriate additional financial resources for developmental impact. Taking a blended finance approach may be useful in this regard. However, this requires greater flexibility, common understanding, and ability to utilize a wider range of funding tools suitable to different stakeholders.

ODA providers and governments, as well as traditional development partners such as Non-Governmental Organizations (NGOs), also need to appreciate the challenges facing private capital providers-in particular institutional investors who have strict fiduciary responsibilities. At the same time, private investors must appreciate the need for demonstrating social and environmental impact when public resources are utilized. Designing effective blended finance mechanisms to support the transition to sustainable agriculture requires an appreciation of the challenges on both the demand for and supply of capital. It is critical that the design of financing structures, including the selection of blended finance instruments and approaches be tailored to the specific situation, including the development challenge and counterparts.

Across the blended finance, impact investing, and development finance communities pursuing sustainable agriculture, key challenges include efficient and effective impact monitoring of social and environmental performance, testing of new investment strategies, and cultivation of appropriate structures and intermediaries. Within blended finance structures, the strategic roles of concessionary capital will likely need to include the following four types of approaches, as well as modifications and mixtures of these approaches, depending on the context: 'Permanent blended finance'financial structures that will always need to rely on concessionary finance within the capital mix for example in cases where research has been done to indicate this requirement, e.g. in the case of Aceli Africa based on the aforementioned work by CSAF; 'Transitional blended finance'-concessionary capital element can taper down as the investment moves past proof of concept, e.g. where a government agency may offer a partial guarantee for an agricultural investment fund to help mobilize private capital, such governmentbacked guarantees typically only cover a certain quantity of transactions; 'Adjustable blended finance'-inclusion of concessionary capital varies based on relevant risk or impact creation, e.g. the Social Impact Incentives (SIINC) mechanism developed by the Swiss Agency for Development and Cooperation (SDC) with Roots of Impact (Roots of Impact 2016), and 'Impact monitoring and verification blended finance'-concessionary capital covers the cost of monitoring or verifying impact, for example where government donors provided a technical assistance facility to the African Agriculture Fund (Marchand).

Efficient, effective agricultural finance has a number of persistent challenges especially in rural emerging market areas. Sustainable agriculture is a particularly relevant target for blended finance given its significant GDP contribution in many countries, and the need to overcome barriers such as the remote location of counterparties, lack of information, and high opportunity costs. Interesting entry points may be found through novel partnerships, for example with agribusinesses, government agencies, technology companies, private capital providers, and NGOs.

There is widespread agreement that we are at a tipping point in many respects, in all three of the dimensions noted in the Brundtland Report: inequality has risen in the past half-century (Credit Suisse 2019), according to the OECD ODA is stagnant (OECD 2018a, b), and many planetary boundaries are at a critical point (Stockholm Resilience Centre). There is widespread agreement, both in the international development community and also the private sector that more needs to be done to address the SDGs, and that this will require significant additional investment. Blended finance is an important lever in mobilizing this additional investment, and although the engagement of private capital has been rather nascent, the rate of growth in the sustainable and impact investing market has been impressive (GSIA 2018), and there have been increasing impact investing allocations to agriculture (GIIN 2019). If used properly, the public sector can encourage more investment to achieve the SDGs, including in the agricultural sector.

The COVID-19 Pandemic has arguably hastened the need to explore such blended finance approaches. The Pandemic, and responses to it are negatively impacting the agriculture sector, including capital flows notably access to critical working capital for agricultural SMEs in emerging and developing markets (ISF et al. 2020). Public funders should consider immediate steps they can take to help facilitate increased access to working capital for vulnerable groups, as well as planning for how to support the medium to long-term investments that will be required to rebuild agricultural-dependent economies. Public sector budgets are likely to become even further stressed as a result of the Pandemic, and thus the need for blended finance solutions may be heightened in both the near and long-term. 


\section{Conclusions}

While policy action to address the SDGs is critical, both from a macro-economic and an agriculture sector perspective, significant private investment in sustainable agriculture must be mobilized in order to meet the SDGs. Historical data makes it clear that the public sector and traditional ODA can contribute to only a fraction of the funding gap to transition to sustainable agriculture. Financing approaches that are based on the 'blending' of public and private capital sources will be necessary to amplify public investment and to attract private capital. Blended finance transactions can help address many different challenges, but, given the scarcity of concessionary finance, should be used in a manner that maximizes impact. Building on the existing basic tools and initial examples, growth of the blended finance market will depend on better understanding of successes and failures by quickly and transparently testing a wide range of partnerships, solutions, and approaches.

\section{References}

ADB, ICD, IDB, EDFI, AfDB, AIIB, EBRD, IFC, EIB. 2017. DFI Working Group on Blended Concessional Finance for Private Sector Projects. Summary Report. https://www.ifc. org/wps/wcm/connect/a8398ed6-55d0-4cc4-95aa-bcbab e39f79f/DFI+Blended+Concessional+Finance+for+Priva te+Sector+Operations_Summary+R....pdf?MOD=AJPER $E S \& C V I D=1 Y C L e 0 B$. Accessed 15 June 2020.

African Capital Markets News website https://www.africancapitalm arketsnews.com , e.g. the news story published 19th, 2018: Liquidity and cost of trading on Africa's stock exchangesBright Africa 2018. https://www.africancapitalmarketsnews .com/3785/liquidity-and-cost-of-trading-on-africas-stock-excha nges-bright-africa-2018/. Accessed 14 June 2020.

AGRA. 2019. Africa Agriculture Status Report: The Hidden Middle: A Quiet Revolution in the Private Sector Driving Agricultural Transformation (Issue 7). Nairobi, Kenya: Alliance for a Green Revolution in Africa (AGRA). https://agra.org/wp-conte nt/uploads/2019/09/AASR2019-The-Hidden-Middleweb.pdf. Accessed 26 May 2020.

Blue Orchard. 2018. Blended Finance 2.0: Giving voice to the Private Sector. Insights from a BlueOrchard survey on private investors, October 2018. https://www.blueorchard.com/ wp-content/uploads/181016_BlueOrchard_Blended_Finance2.0.pdf. Accessed 26 May 2020.

Bioversity International, CGIAR, Clarmondial. 2017. Reducing risks and seizing opportunities: integrating biodiversity into food and agriculture investments. Bioversity International, Rome, Italy. https://www.clarmondial.com/wp-content/uploads/2017/07/ ABD_Index_Investor_summary.pdf. Accessed 26 May 2020.

Cambridge Dictionary. Real economy. https://dictionary.cambridge. org/dictionary/english/real-economy. Accessed 26 May 2020.

Carter, P., Van De Sijpe, N. and Calel, R. 2018. The elusive quest for additionality. Working Paper 495. Washington, D.C.: Center for Global Development. www.cgdev.org/sites/default/files/elusi ve-quest-additionality.pdf. Accessed 26 May 2020.
CGIAR. 2014. Increasing homogeneity of world food supplies warns of serious implications for farming and nutrition. ScienceDaily. www.sciencedaily.com/releases/2014/03/140303154102.htm. Accessed 26 May 2020.

Clarmondial, Wageningen University \& Research, Versant Vision. 2019. EIRA: Environmental Impact Reporting in Agriculture. Creating a link between agricultural investments and environmental impact. https://static1.squarespace.com/static/56cb8cc14d 088ea8995336de/t/5ca13ceb6e9a7f3e80ba8c5b/1554070764244/ EIRA_Report_April_2019.pdf. Accessed 26 May 2020.

Convergence. 2019. The State of Blended Finance 2019. https://asset s.ctfassets.net/4cgqlwde6qy0/58T9bhxExlNh2RilxWxSNe/ba56f a36c81349640179779ddd68cc99/Convergence_-_The_State_of_ Blended_Finance_2019.pdf. Accessed 26 May 2020.

Council on Smallholder Agricultural Finance (CSAF). 2019. State of the Sector 2019. https://csaf.org/wp-content/uploads/2019/07/ CSAF_State_of_Sector_2019_Full_Final.pdf. Accessed 26 May 2020.

Credit Suisse. October 2019. Research Institute. Global Wealth Report 2019.

Dalberg Global Development Advisers. 2018. Blended finance tools to catalyze investment in agricultural value chains: An initial toolbox.

EIB. 16 January 2017. Quasi-equity: A new financial structure for a new challenge. https://www.eib.org/en/stories/quasi-equity-a-newfinancial-structure-for-a-new-challenge. Accessed 26 May 2020.

ESPON. 2017. Policy Brief. Shrinking rural regions in Europe. Towards smart and innovative approaches to regional development challenges in depopulating rural regions. Luxembourg, European Union, ESPON. https://www.espon.eu/sites/default/files/attac hments/ESPON\%2520Policy\%2520Brief\%2520on\%2520Shrink ing\%2520Rural\%2520Regions.pdf. Accessed 26 May 2020.

FABLE. 2019. Pathways to Sustainable Land-Use and Food Systems. 2019 Report of the FABLE Consortium. Laxenburg and Paris: International Institute for Applied Systems Analysis (IIASA) and Sustainable Development Solutions Network (SDSN).

FAO. https://www.fao.org/3/i2490e/i2490e01c.pdf. Accessed 26 May 2020.

FAO. 2013. Climate Smart Agriculture Sourcebook. Rome, FAO. https ://www.fao.org/3/i3325e/i3325e.pdf. Accessed 26 May 2020.

FAO. 2017. The future of food and agriculture. Trends and challenges. Rome, FAO. https://www.fao.org/3/a-i6583e.pdf. Accessed 26 May 2020.

FAO and DWFI. 2015. Yield gap analysis of field crops: Methods and case studies, by Sandras V.O., Cassman, K.G.G., Grassini, P., Hall, A.J., Bastiaanssen, W.G.M., Laborte, A.G., Milne, A.E., Sileshi, G., Steduto, P. FAO Water Reports No 41, Rome, Italy. https://www.fao.org/3/a-i4695e.pdf. Accessed 26 May 2020.

FAO, IFAD, UNICEF, WFP and WHO. 2018. The State of Food Security and Nutrition in the World 2018. Building climate resilience for food security and nutrition. Rome, FAO. https://www.fao. org/3/19553EN/i9553en.pdf. Accessed 26 May 2020.

GIIN. 2018. Annual Impact Investor Survey 2018. The Eighth Edition. https://thegiin.org/assets/2018_GIIN_Annual_Impact_Inves tor_Survey_webfile.pdf. Accessed 14 June 2020.

GIIN. 2019. Annual Impact Investor Survey 2019. The Ninth Edition. https://thegiin.org/assets/GIIN_2019\%2520Annual\%2520Impact \%2520Investor\%2520Survey_webfile.pdf. Accessed 26 May 2020.

Global Center on Adaptation and World Resources Institute. 2019. Adapt Now: A Global Call For Leadership on Climate Resilience. https://cdn.gca.org/assets/2019-09/GlobalCommission_Repor t_FINAL.pdf. Accessed 26 May 2020.

Global Impact Investing Network (GIIN). All You Need to Know about Impact Investing. https://thegiin.org/impact-investing/. Accessed 26 May 2020. 
Global Sustainable Investment Alliance (GSIA). 2018. Trends Report 2018. https://www.gsi-alliance.org/trends-report-2018/. Accessed 14 June 2020.

IDFC. 2019. Blended Finance: A Brief Overview. https://www.idfc. org/wp-content/uploads/2019/10/blended-finance-a-brief-overv iew-october-2019_final.pdf. Accessed 15 June 2020.

IFAD. 2019. Creating opportunities for rural youth. 2019 Rural Development Report. Rome, IFAD. https://www.ifad.org/docum ents/38714170/41133075/RDR_report.pdf/7282db66-2d67-b514d004-5ec25d9729a0. Accessed 14 June 2020.

Investopedia. Private equity vs. Public equity: What's the difference? https://www.investopedia.com/articles/investing/030415/diffe rence-between-private-and-public-equity.asp Accessed 15 June 2020

IPCC. 2019. IPCC Special Report on Climate Change, Desertification, Land Degradation, Sustainable Land Management, Food Security, and Greenhouse gas fluxes in Terrestrial Ecosystems. Summary for Policymakers. Approved Draft. https://www.ipcc.ch/site/asset s/uploads/2019/08/4.-SPM_Approved_Microsite_FINAL.pdf. Accessed 26 May 2020.

ISF, Mastercard Foundation and Rural \& Agricultural Finance Learning Lab. 2020. COVID-19 Emergency Briefing. https://www. raflearning.org/post/covid-19-emergency-briefing-agri-smesoperating-uncertain-financial-operational-and-supply Accessed 14 June 2020.

Marchand, Sarah. Reflections on the effectiveness of TA provided by facilities linked with investment funds. https://www.inclusiveb usiness.net/ib-voices/reflections-effectiveness-ta-provided-facil ities-linked-investment-funds. Accessed 14 June 2020.

Milken Institute \& OECD. 2018. Guaranteeing the goals: Adapting public sector guarantees to unlock blended financing for the UN Sustainable Development Goals. https://assets1c.milkeninstitute .org/assets/Publication/Viewpoint/PDF/Guaranteeing-the-Goals -FINAL-4.pdf. Accessed 26 May 2020.

Musgrove, P. 2011. Financial and Other Rewards for Good Performance or Results: A Guided Tour of Concepts and Terms and a Short Glossary. World Bank Group. Online: https://www.rbfhe alth.org/sites/rbf/files/RBFglossarylongrevised_0.pdf. Accessed 14 June 2020.

ODI. 2019. Blended finance in the poorest countries-The need for a better approach. https://www.odi.org/sites/odi.org.uk/files/resou rce-documents/12666.pdf. Accessed 26 May 2020.

OECD. Blended Finance: Bridging the Sustainable Development Finance Gap. https://www.oecd.org/dac/financing-sustainabl e-development/development-finance-topics/Blended-FinanceBridging-SDG-Gap.pdf. Accessed 26 May 2020.

OECD. 2018a. The next step in blended finance: Addressing the evidence gap in development performance and results. As part of the consultation on the OECD DAC Blended Finance Principles for unlocking commercial finance for the SDGs. Copenhagen, Denmark, Monday 22 October 2018. Workshop report. https://www. oecd.org/dac/financing-sustainable-development/developmen t-finance-topics/OECD-Blended\%2520Finance-Evidence-Gapreport.pdf. Accessed 26 May 2020.

OECD. 2018b. Making Blended Finance Work for the Sustainable Development Goals, OECD Publishing, Paris. https://read.oecdilibrary.org/development/making-blended-finance-work-forthe-sustainable-development-goals_9789264288768-en\#page3. Accessed 26 May 2020

OECD. Development aid drops in 2018, especially to neediest countries: https://www.oecd.org/development/development-aid-drops -in-2018-especially-to-neediest-countries.htm. Accessed 14 June 2020.

OECD. February 2019. Amounts mobilised from the private sector by development finance interventions in 2016-2017. Preliminary insights from the data. https://www.slideshare.net/OECDd ev/amountsmobilisedfromtheprivatesectorbydevelopmentfinanc einterventionsin201217. Accessed 26 May 2020.

Oliver Wyman \& World Federation of Exchanges. Enhancing liquidity in emerging market exchanges. https://www.world-excha nges.org/storage/app/media/research/Studies_Reports/liqui dity-in-emerging-market-exchanges-wfe-amp-ow-report.pdf. Accessed 14 June 2020.

Pereira, J. 2015. Leveraging aid: A literature review on the additionality of using ODA to leverage private investments. London: UK Aid Network.

Roots of Impact. SIINC in Practice. https://www.roots-of-impact.org/ siinc-programs/ and SDC with Roots of Impact. 2016. SIINC White Paper. https://www.roots-of-impact.org/wp-content/uploa ds/2019/01/Social-Impact-Incentives-SIINC-White-Paper-2016. pdf. Accessed 14 June 2020.

SAFIN. March 2019. Landscape Report: Blended Finance for Agriculture. https://5724c05e-8e16-4a51-a320-65710d75ed23.files usr.com/ugd/7f0ffd_d48e2795163446d88b574c2c5c3ade0a.pdf. Accessed 16 June 2020.

Santa Clara University. 2013. Demand dividend: Creating Reliable Returns in Impact Investing. https://thegiin.org/assets/Santa $\% 2520$ Clara\%2520U_Demand-Dividend-Description.pdf. Accessed 26 May 2020.

Stockholm Resilience Centre. The nine planetary boundaries. https ://www.stockholmresilience.org/research/planetary-boundaries /planetary-boundaries/about-the-research/the-nine-planetaryboundaries.html. Accessed 14 June 2020.

Swiss Sustainable Finance Glossary. https://www.sustainablefina nce.ch/en/glossary-_content---1--3077.html. Accessed 26 May 2020.

UK National Archives. January 2015. Operational Selection Policy OSP49. Records of UK Export Finance, 1978 onwards. https ://www.nationalarchives.gov.uk/documents/information-manag ement/OSP49.pdf. Accessed 15 June 2020.

UNCTAD and Convergence. Blended Finance. https://www.conve rgence.finance/blended-finance. Accessed 26 May 2020.

United Nations. 1987. Our common future, Brundtland Report. https ://www.are.admin.ch/are/en/home/sustainable-development/ international-cooperation/2030agenda/un-_-milestones-in-susta inable-development/1987--brundtland-report.html. Accessed 26 May 2020.

Velten, S., J. Leventon, N. Jager, and J. Newig. 2015. What is sustainable agriculture? A systematic review. Sustainability 2015 (7): 7833-7865.

World Bank Data: Agriculture, forestry and fishing, value added (\% of GDP) website. https://data.worldbank.org/indicator/ NV.AGR.TOTL.ZS?most_recent_value_desc=true. Accessed 15 June 2020.

World Bank Group. 2014. Introduction to agricultural insurance and risk management. Manuel 1. Washington DC: International Finance Corporation.

Zhao, C., B. Liu, S. Piao, X. Wang, D.B. Lobell, Y. Huang, M. Huang, Y. Yao, S. Bassu, P. Ciais, J.L. Durand, J. Elliott, F. Ewert, I.A. Janssens, T. Li, E. Lin, Q. Liu, P. Martre, C. Müller, S. Peng, J. Peñuelas, A.C. Ruane, D. Wallach, T. Wang, D. Wu, Z. Liu, Y. Zhu, Z. Zhu and S. Asseng. 2017. Temperature increase reduces global yields of major crops in four independent estimates. Proceedings of the National Academy of Sciences of the United States of America (PNAS) in PNAS August 29, 2017114 (35): 9326-9331. https://www.pnas.org/conte nt/114/35/9326. Accessed 26 May 2020.

Publisher's Note Springer Nature remains neutral with regard to jurisdictional claims in published maps and institutional affiliations. 
Tanja Havemann is the co-founder and director of Clarmondial AG, a Swiss advisory firm focused on investments in sustainable natural resource management. She holds academic qualifications in environmental sciences (University of Aberdeen), environmental economics (Imperial College London) and environmental law and policy (University of Kent, Canterbury). Tanja has authored articles and white papers on sustainable investments, primarily on climate smart agriculture and blended finance in emerging markets.

Dr. Christine Negra, Versant Vision LLC is an international consultant specializing in climate change, sustainable agriculture, and integrated landscape management. As a soil chemist with over 25 years of experience as an Extension agent, a researcher, and a program director, she collaborates with development, research, and finance organizations on multi-disciplinary initiatives that link science to policy and markets.

Fred Werneck is the co-founder of Clarmondial AG, a Swiss advisory firm focused on investments in sustainable natural resource management. He holds an MBA from London Business School and a bachelor in economics and finance (IBMEC, Brazil). Fred has extensive experience in private investments in emerging markets, and he has published papers on sustainable investments. 